\title{
Vitamin D deficiency and the course of SARS-CoV-2 infection
}

\author{
Niedobory witaminy D a przebieg zakażenia SARS-CoV-2
}

\author{
1 Department of Paediatrics, Paediatric Nephrology and Allergology, Military Institute of Medicine, Warsaw, Poland \\ ${ }^{2}$ Department of Regenerative Medicine and Cell Biology, Military Institute of Hygiene and Epidemiology, Warsaw, Poland \\ ${ }^{3}$ UnivRennes, UMR 6290, CNRS, Institute of Genetics and Development of Rennes, Cell Cycle Group, Faculty of Medicine, Rennes, France \\ Correspondence: Agnieszka Lipińska-Opałka, Szaserów 128, 04-141 Warsaw, Poland, tel.: +48 261817 236, e-mail: alipinska@wim.mil.pl
}

Abstract Vitamin D is a fat-soluble steroid hormone. Its main role is to regulate calcium and phosphate levels, which are strictly associated with ossification and bone homeostasis. However, due to the presence of a nuclear vitamin D receptor (VDR) in the majority of cells of the human body, vitamin $\mathrm{D}$ also displays multiple effects beyond the bones. Calcitriol $\left(1,25(\mathrm{OH})_{2} \mathrm{D}\right)$ not only affects cell growth and differentiation, but also stimulates the immune system by, for example, modulating the production of IL- 4 and IL- 5 anti-inflammatory cytokines. High numbers of VDRs have been found on macrophages, dendritic cells and lymphocytes, among other cells, which can be considered a very strong argument for the participation of vitamin $\mathrm{D}$ in autoimmune and anti-inflammatory processes. In recent months we have been witnessing the development of the COVID-19 pandemic. One of the most dangerous consequences of SARS-CoV-2 infection is acute respiratory distress syndrome caused by the activation of lung macrophages and the so-called cytokine storm. A recent study on COVID-19 patients suggests that vitamin D activates the innate immune response and suppresses the acquired immune response; the resultant decreased cytokine expression can reduce the severity of inflammation associated with COVID-19. Among older children and adults, vitamin D deficiency is widespread and observed worldwide, including in the Polish population. Based on numerous studies, normal serum vitamin D levels were established. Vitamin D concentration below $20 \mathrm{ng} / \mathrm{mL}$ is considered deficient and a level between 20 and $30 \mathrm{ng} / \mathrm{mL}$ is regarded as suboptimal. An optimal vitamin D concentration is $30-50 \mathrm{ng} / \mathrm{mL}$.

Keywords: SARS-CoV-2, COVID-19, vitamin D, macrophages

Streszczenie Witamina D jest rozpuszczalnym w tłuszczach hormonem steroidowym, którego główna rola polega na regulacji gospodarki wapniowo-fosforanowej, ściśle związanej z kostnieniem i homeostazą kości. Jednak ze względu na obecność jądrowego receptora dla witaminy D (VDR) w większości komórek ludzkiego organizmu wykazuje ona także liczne działania pozakostne. Kalcytriol $\left(1,25(\mathrm{OH})_{2} \mathrm{D}\right)$ nie tylko wpływa na wzrost i różnicowanie komórek, ale również pobudza układ immunologiczny, np. poprzez modulację produkcji cytokin przeciwzapalnych IL-4 i IL-5. Obecność dużej liczby receptorów VDR stwierdzono m.in. na makrofagach, komórkach dendrytycznych i limfocytach, co można uznać za bardzo mocny argument wskazujący na udział witaminy D w procesach autoimmunologicznych i przeciwzapalnych. W ostatnich miesiącach obserwujemy rozwój pandemii COVID-19. Jednym z najgroźniejszych skutków zakażenia wirusem SARS-CoV-2 jest zespół ostrej niewydolności oddechowej spowodowany aktywacją makrofagów płucnych i tzw. burzą cytokinową. Niedawna analiza obejmująca chorych z COVID-19 sugeruje, że witamina D aktywuje wrodzoną i tłumi nabytą odpowiedź immunologiczną, która poprzez obniżenie poziomu ekspresji cytokin może zmniejszyć nasilenie procesu zapalnego w przebiegu COVID-19. Wśród starszych dzieci i dorosłych niedobory witaminy D są powszechne i obserwowane na całym świecie, również w populacji polskiej. Na podstawie licznych badań ustalono normy stężenia witaminy $\mathrm{D}$ w surowicy. Za niedobór uznaje się stężenie poniżej $20 \mathrm{ng} / \mathrm{ml}$, a za stężenie suboptymalne wartości między 20 a $30 \mathrm{ng} / \mathrm{ml}$. Optymalne stężenie witaminy D mieści się w granicach 30-50 ng/ml.

Słowa kluczowe: SARS-CoV-2, COVID-19, witamina D, makrofagi 


\section{INTRODUCTION}

$\mathrm{T}$ he first cases of the disease caused by the SARS$\mathrm{CoV}-2$ virus (severe acute respiratory syndrome coronavirus 2) were recorded in December 2019 in Wuhan, China. Since that time, coronavirus disease 19 (COVID-19) has spread worldwide, reaching pandemic levels ${ }^{(1)}$. Individuals with chronic conditions, cardiovascular diseases, diabetes, respiratory illnesses and people aged over 60 are at a greater risk of a severe course of COVID-19. To date, no targeted therapy for this type of virus has been discovered, but first vaccines are already available. For this reason, it is very important to determine factors which can alleviate the severity of the disease and reduce the associated mortality. Vitamin D has a proven effect on reducing the prevalence and severity of respiratory infections; therefore, its role in the pathogenesis and course of SARS-CoV-2 infection should be investigated $^{(2)}$.

\section{VITAMIN D METABOLISM}

Vitamin D is a fat-soluble steroid hormone. Its main role is to regulate calcium and phosphate levels in the body. There are three forms of vitamin D: calciferol, which is naturally found mainly in fish fat, ergocalciferol, which is present in plants, and cholecalciferol, which is obtained by endogenous synthesis ${ }^{(3,4)}$.

Under the influence of UVB radiation of $280-315 \mathrm{~nm}$ wavelength, previtamin $\mathrm{D}$ is formed from 7-dehydrocholesterol (provitamin D) present in keratinocytes in the skin. Previtamin D is thermodynamically unstable and is quickly transformed to cholecalciferol. Cholecalciferol binds to the vitamin D binding protein (DBP) and is transported to many organs ${ }^{(4,5)}$. Cutaneous synthesis of vitamin $\mathrm{D}$ depends on the angle of sun's rays, time of day and the use of products which prevent UVB rays from reaching deeper layers of the skin. In Poland, cutaneous synthesis is possible from the middle of April to the middle of September; the highest synthesis takes place in the middle of the day, when the sun is at its zenith. The use of products with a sun protection factor (SPF) of more than 8 effectively blocks the production of cholecalciferol ${ }^{(3,5)}$.

In the mitochondria and microsomes of hepatic cells, cholecalciferol is converted to 25 -hydroxyvitamin D $(25(\mathrm{OH}) \mathrm{D})$ using 25 -hydroxylase. The catalysts for this process include CYP27A1 (mitochondria), CYP2R1 (microsomes) and cytochrome P450 enzymes: CYP3A4 and $\mathrm{CYP} 2 \mathrm{~J}^{(3)}$.

The production of $25(\mathrm{OH}) \mathrm{D}$ is not tightly regulated. Increased cutaneous synthesis and oral supplementation of vitamin D result in an increase of serum 25(OH)D level. Due to a relatively long half-life (approximately 3 weeks) and chemical stability, this metabolite is used to assess vi-
At a subsequent stage, 25(OH)D is converted to $1,25(\mathrm{OH})_{2} \mathrm{D}$ (calcitriol) in proximal renal tubules using 1a-hydroxylase. Calcitriol is a biologically active form of vitamin D. The process of its formation is catalysed by CYP27B1 ${ }^{(3)}$. The $1,25(\mathrm{OH})_{2} \mathrm{D}$ half-life is short and lasts only 4-6 hours; for this reason, calcitriol levels are not used to assess the body's vitamin $\mathrm{D}$ stores ${ }^{(3-6)}$. The production of calcitriol $\left(1,25(\mathrm{OH})_{2} \mathrm{D}\right)$ is tightly regulated and depends on serum levels of calcium and phosphates.

The ability to produce $1,25(\mathrm{OH})_{2} \mathrm{D}$ was also demonstrated for other organs, tissues and cells, e.g. macrophages, osteoblasts, keratinocytes, the prostate, the large intestine, mammary glands and the placenta. The aim of the production of this metabolite in organs other than the kidneys is probably to regulate various biological processes, e.g. growth and apoptosis, angiogenesis or differentiation of immune cells ${ }^{(3)}$.

Both $25(\mathrm{OH}) \mathrm{D}$ and $1,25(\mathrm{OH})_{2} \mathrm{D}$ are catabolised using 24-hydroxylase (CYP24A1). This results in an inactive form of $1,24,25$-trihydroxyvitamin $\mathrm{D}\left(1,24,25(\mathrm{OH})_{3} \mathrm{D}\right)$. The concentration of 24-hydroxylase is regulated by $1,25(\mathrm{OH})_{2} \mathrm{D}$ through the nuclear vitamin $\mathrm{D}$ receptor $(\mathrm{VDR})^{(3)}$. Calcitriol binds to VDR, and through a bond with DNA it regulates the activity of approximately 2,000 genes, which are part of many metabolic pathways. It was proven that calcitriol $\left(1,25(\mathrm{OH})_{2} \mathrm{D}\right)$ not only affects cell growth and differentiation, but it also stimulates the immune system (e.g. by modulating the production of anti-inflammatory cytokines: interleukins 4 and 5) ${ }^{(5-7)}$.

\section{ROLE OF VITAMIN D IN THE IMMUNE SYSTEM}

The presence of VDR and activity of 1 -hydroxylase was found in practically all tissues and cells of the body, including in the macrophages, dendritic cells and lymphocytes, which suggests that vitamin D plays an important role in autoimmune and anti-inflammatory processes $^{(6-8)}$.

In monocytes and macrophages, toll-like receptors (TLRs) can also be found, which are regulated by vitamin $\mathrm{D}$ response elements (VDREs), which allow binding with VDRs. In this way, so-called natural antibiotics are formed: cathelicidin and defensin, which code for antimicrobial peptides, which reduce the rate of viral replication and promote chemotaxis of macrophages and other immune cells during inflammation $^{(9)}$.

One of recently proven functions of VDR is its influence on the development, differentiation and functions of T-cells and dendritic cells ${ }^{(10)}$. Research on mice demonstrated that their vitamin D receptor knockout (VDR-KO) cells display a more pronounced reaction of proinflammatory Th17 effector cells responsible for producing the proinflammatory IL-17. In contrast, increased VDR expression inhibits the transcription of the IL-2 gene, thus preventing immune system overload ${ }^{(10,11)}$. 
Recent research demonstrated that macrophages, including those present in pulmonary alveoli, play a key role in the development of the so-called cytokine storm in the lungs of COVID-19 patients due to the presence of 1a-hydroxylase (CYP27B1) on their surface, which transforms an inactive form of vitamin $\mathrm{D}$ into its active metabolite $1,25(\mathrm{OH})_{2} \mathrm{D}$. This metabolite binds to macrophage VDRs ${ }^{(12)}$. It was demonstrated in a murine model that VDR deletion in macrophages decreases immune response in skin damage and results in compromised wound healing ${ }^{(13)}$. In a study on mice, Zhang et al. ${ }^{(14)}$ found that vitamin $\mathrm{D}$ supplementation increased the expression of mitogen-activated protein kinase phosphatase 1 (MKP-1), which resulted in the inhibition of proinflammatory IL- 6 and tumour necrosis factor $\alpha$ (TNF- $\alpha$ ) production in monocytes and macrophages. It is still unknown whether as a result of binding with vitamin $\mathrm{D}$, VDRs are permanently located in the cellular nucleus or move between the nucleus and cytoplasm ${ }^{(15)}$. Research on cystic fibrosis, a chronic lung disease, demonstrated that by acting through its receptors, vitamin D increases the transcription of anti-inflammatory dual specificity protein phosphatase 1 (DUSP1) gene, which decreases the expression of the proinflammatory IL-8 chemokine produced by overreactive macrophages ${ }^{(16)}$. These results suggest a high therapeutic potential of vitamin $\mathrm{D}$ in the treatment of inflammatory lung diseases. Moreover, a recent study on COVID-19 patients suggests that vitamin $\mathrm{D}$ activates the innate immune response and suppresses the acquired immune response; the resultant decreased cytokine expression can reduce the severity of inflammation associated with COVID-19 $9^{(16-18)}$. It was also demonstrated that by promoting the development of tolerogenic dendritic cells and induced regulatory suppressor T-cells (iTregs) responsible for immune balance, vitamin $\mathrm{D}$ prevents a potentially excessive immune response $^{(10,19)}$. VDR also plays a key role in normal mitochondrial function and prevents increased respiratory activity and the production of reactive oxygen species (ROS), which are important activators of proinflammatory reaction in macrophages ${ }^{(20-22)}$. Already a hundred years ago, in the pre-antibiotic era, sun exposure or consumption of fish oil were used in the treatment of tuberculosis, which increased the concentration of vitamin D in the body. Currently, vitamin D supplementation is also used as adjuvant treatment against tuberculosis ${ }^{(23)}$.

Analysis of data concerning patients with COVID-19 from all over the world indicates that there is a risk of a more severe course of the disease in patients with severe vitamin D deficiency ${ }^{(16)}$.

One of the most dangerous consequences of SARS-CoV-2 infection is the development of acute respiratory distress syndrome (ARDS) caused by the activation of lung macrophages and the so-called cytokine storm. Macrophage induction can occur via two paths: external and internal. Both are strictly associated with the activation of the angiotensin-converting enzyme 2 (ACE2) receptor ${ }^{(23,24)}$.

\begin{tabular}{|c|c|c|}
\hline Descriptive label & \multicolumn{2}{|c|}{ Serum 25(OH)D level } \\
\hline Measurement units & $\mathbf{n m o l} / \mathbf{L}$ & $\mathbf{n g} / \mathbf{m L}$ \\
\hline Deficiency & $0-50$ & $0-20$ \\
\hline Suboptimal level & $50-75$ & $20-30$ \\
\hline Optimal level & $75-125$ & $30-50$ \\
\hline High level & $125-250$ & $50-100$ \\
\hline Potentially toxic level & $>250$ & $>100$ \\
\hline Toxic level & $>500$ & $>200$ \\
\hline
\end{tabular}

Tab. 1. Assessment of body stores of vitamin D based on serum 25(OH)D concentration

It is currently known that children contract SARS-CoV-2 less frequently than adults and have an asymptomatic infection or less severe symptoms more frequently than adults ${ }^{(25-27)}$. The immune system of infants and very small children is not fully developed yet ${ }^{(28)}$ and their innate immune response, which is based on monocytes, macrophages, dendritic cells and neutrophils, is relatively weak and is associated with a distinctly lower cytokine response than in adults ${ }^{(27,28)}$.

Among older children and adults, vitamin D deficiency is widespread and observed worldwide, including in the Polish population. Based on numerous studies, normal serum vitamin D levels were determined (Tab. 1).

The vitamin $\mathrm{D}$ deficit observed in the population is probably caused by progressing lifestyle change, i.e. mainly longer time spent in closed spaces and the concomitant shorter sunlight exposure. Individuals with chronic diseases are at a particular risk of vitamin $\mathrm{D}$ deficiency ${ }^{(29)}$.

In 2013, based on a systematic literature review, a team of experts developed guidelines regarding vitamin $\mathrm{D}$ supplementation for Central Europe that established recommended doses for the healthy population and for groups at risk of vitamin D deficiency. These data were updated in 2018 (Tab. 2-4) ${ }^{(29)}$. In patients with laboratory confirmation of vitamin D deficiency, supplementation should last until an optimal serum level of $25(\mathrm{OH}) \mathrm{D}$ is reached $(30-50 \mathrm{ng} / \mathrm{mL})$, but not shorter than a month; vitamin $\mathrm{D}$ should preferably be administered for 1 to 3 months ${ }^{(29)}$.

\section{CONCLUSIONS}

It seems that the influence of vitamin $\mathrm{D}$ on the modulation of inflammation and inhibition of excessive immune response can contribute to alleviating the course of viral infections, including SARS-CoV-2 infection. People in whom vitamin $\mathrm{D}$ deficiency is often observed (elderly individuals, patients with chronic diseases) are at risk of a particularly severe course of the disease and high mortality. Therefore, vitamin D supplementation may be an effective means of alleviating the processes involved in COVID-19 infection.

\section{Conflict of interest}

The authors do not report any financial or personal affiliations to persons or organisations that could adversely affect the content of or claim to have rights to this publication. 


\begin{tabular}{|c|c|c|}
\hline Age & Recommended vitamin D dose & Comments \\
\hline $0-6$ months & $\begin{array}{l}400 \mathrm{IU} / \text { day } \\
(10.0 \mu \mathrm{g} / \text { day })\end{array}$ & Vitamin D supplementation should be introduced already in the first days of life \\
\hline $6-12$ months & $\begin{array}{c}400-600 \mathrm{IU} / \text { day } \\
(10.0-15.0 \mu \mathrm{g} / \text { day })\end{array}$ & Dose calculated based on vitamin D content in the child's diet \\
\hline $1-18$ years & $\begin{array}{l}600-1,000 \mathrm{IU} / \text { day } \\
(15.0-25.0 \mu \mathrm{g} / \text { day })\end{array}$ & $\begin{array}{l}\text { Recommended dose: } \\
\text { - from September to April } \\
\text { - for the whole year if sufficient cutaneous vitamin D synthesis is not possible during the summer } \\
\text { The dose depends on body mass }\end{array}$ \\
\hline $18-65$ years & $\begin{array}{l}800-2,000 \mathrm{IU} / \text { day } \\
(20.0-50.0 \mu \mathrm{g} / \text { day })\end{array}$ & $\begin{array}{l}\text { Recommended dose: } \\
\text { - from September to April } \\
\text { - for the whole year if sufficient cutaneous vitamin D synthesis is not possible during the summer } \\
\text { The dose depends on body mass }\end{array}$ \\
\hline$>65$ years & $\begin{array}{l}800-2,000 \mathrm{IU} / \text { day } \\
(20.0-50.0 \mu \mathrm{g} / \text { day })\end{array}$ & $\begin{array}{l}\text { Supplementation is recommended for the whole year due to decreased cutaneous synthesis } \\
\text { of vitamin D }\end{array}$ \\
\hline
\end{tabular}

Tab. 2. Recommendations regarding vitamin D supplementation in the general population

\begin{tabular}{|c|c|c|}
\hline Group & Vitamin D dose & Comments \\
\hline $\begin{array}{c}\text { Women who are planning } \\
\text { pregnancy }\end{array}$ & $\begin{array}{c}800-2,000 \mathrm{IU} / \text { day } \\
(20.0-50.0 \mu \mathrm{g} / \mathrm{day})\end{array}$ & $\begin{array}{l}\text { In the second trimester of pregnancy at the latest. Introduction of the recommended dose upon confirmation } \\
\text { of pregnancy to be considered. Monitoring of the vitamin D level and dose modification to be considered (aim: } \\
\text { serum } 25(0 \mathrm{H}) \mathrm{D} \text { concentration of } 30-50 \mathrm{ng} / \mathrm{mL} \text { or } 75-125 \mathrm{nmol} / \mathrm{L})\end{array}$ \\
$\begin{array}{c}\text { Pregnant and nursing } \\
\text { women }\end{array}$ & $\begin{array}{c}1,500-2,000 \mathrm{IU} / \mathrm{day} \\
(37.5-50.0 \mu \mathrm{g} / \mathrm{day})\end{array}$ & \\
\hline
\end{tabular}

Tab. 3. Recommendations regarding vitamin D supplementation in women who are planning pregnancy, are pregnant or are breastfeeding

\begin{tabular}{|c|c|c|}
\hline Vitamin D deficiency risk group & Recommended vitamin D dose & Comments \\
\hline Preterm children & $\begin{array}{l}400-800 \text { IU/day } \\
(10-20 \mu \mathrm{g} / \text { day })\end{array}$ & $\begin{array}{l}\text { Supplementation at a recommended dose until a corrected age of } 40 \text { weeks is } \\
\text { reached; subsequent supplementation in line with recommendations for children } \\
\text { aged } 0-6 \text { months. Supplementation recommended from the first day of life/first day } \\
\text { of enteral nutrition }\end{array}$ \\
\hline $\begin{array}{l}\text { Children and adolescent patients with obesity } \\
\text { (BMI }>90^{\text {th }} \text { percentile for age and gender) }\end{array}$ & $\begin{array}{l}1,200-2,000 \text { IU/day } \\
(30-50 \mu \mathrm{g} / \text { day })\end{array}$ & $\begin{array}{l}\text { Recommended dose: } \\
\text { - from September to April } \\
\text { - for the whole year if sufficient cutaneous vitamin D synthesis is not possible during } \\
\text { the summer } \\
\text { Dose dependent on the level of obesity }\end{array}$ \\
\hline $\begin{array}{l}\text { Adults, obese individuals } \\
\qquad(\mathrm{BMI}>30)\end{array}$ & $\begin{array}{c}1,600-4,000 \text { IU/day } \\
(40-100 \mu \mathrm{g} / \text { day })\end{array}$ & $\begin{array}{l}\text { Dose recommended for the whole year, even with appropriate sunlight exposure } \\
\text { in the summer. Dose dependent on the level of obesity }\end{array}$ \\
\hline Individuals with dark complexion & $\begin{array}{l}1,000-2,000 \text { IU/day } \\
(25-50 \mu \mathrm{g} / \text { day })\end{array}$ & Dose recommended for the whole year, dependent on body mass \\
\hline Individuals who work at night & $\begin{array}{l}1,000-2,000 \text { IU/day } \\
(25-50 \mu \mathrm{g} / \text { day })\end{array}$ & Dose recommended for the whole year, dependent on body mass \\
\hline
\end{tabular}

Tab. 4. Recommendations regarding vitamin D supplementation in groups at risk of deficiency ${ }^{(14,15)}$

\section{References}

1. Centers for Disease Control and Prevention: COVID-19. Available from: https://www.cdc.gov/coronavirus/2019-ncov/index. html [cited: 23 January 2020].

2. Grant WB, Lahore H, McDonnell SL et al.: Evidence that vitamin D supplementation could reduce risk of influenza and COVID-19 infections and deaths. Nutrients 2020; 12: 988.

3. Zerwekh JE: Vitamin D metabolism and stones. In: Rao NP, Preminger GM, Kavanagh JP (eds.): Urinary Tract Stone Disease. Springer, London 2011: 169-179.

4. Holick MF, Chen TC, Lu Z et al.: Vitamin D and skin physiology: a D-lightful story. J Bone Miner Res 2007; 22: 28-33.

5. Nesterova G, Malicdan MC, Yasuda K et al.: 1,25-(OH $)_{2} \mathrm{D}-24$ hydroxylase (CYP24A1) deficiency as a cause of nephrolithiasis. Clin J Am Soc Nephrol 2013; 8: 649-657.

6. Pludowski P, Holick MF, Grant WB et al.: Vitamin D supplementation guidelines. J Steroid Biochem Mol Biol 2018; 175: 125-135.

7. Watkins RR, Lemonovich TL, Salata RA: An update on the association of vitamin $\mathrm{D}$ deficiency with common infectious diseases.
8. Bugadze L, Manjavidze N, Jorjoliani L: Asthma control status and lung function in relation to vitamin $\mathrm{D}$ level in children with bronchial asthma. Georgian Med News 2018; 283: 115-118.

9. Kuźmińska MP: Witamina D a układ oddechowy. Post Nauk Med 2012; 25: 241-246.

10. Kongsbak M, Levring TB, Geisler C et al.: The vitamin D receptor and T cell function. Front Immunol 2013; 4: 148.

11. Bruce D, Yu S, Ooi JH et al.: Converging pathways lead to overproduction of IL-17 in the absence of vitamin D signaling. Int Immunol 2011; 23: 519-528.

12. Adams JS, Sharma OP, Gacad MA et al.: Metabolism of 25-hydroxyvitamin D3 by cultured pulmonary alveolar macrophages in sarcoidosis. J Clin Invest 1983; 72: 1856-1860.

13. Song L, Papaioannou G, Zhao $H$ et al.: The vitamin D receptor regulates tissue resident macrophage response to injury. Endocrinology 2016; 157: 4066-4075.

14. Zhang Y, Leung DYM, Richers BN et al.: Vitamin D inhibits monocyte/macrophage proinflammatory cytokine production by targeting MAPK phosphatase-1. J Immunol 2012; 188: 2127-2135.

15. Di Rosa $M$, Malaguarnera $M$, Nicoletti $F$ et al.: Vitamin $D_{3}$ : a helpful immuno-modulator. Immunology 2011; 134: 123-139. 
16. Daneshkhah A, Agrawal V, Eshein A et al.: The possible role of vitamin D in suppressing cytokine storm and associated mortality in COVID-19 patients. medRxiv 2020. DOI: 10.1101/2020.04.08.20058578.

17. Aranow C: Vitamin D and the immune system. J Investig Med 2011; 59: 881-886.

18. Goncalves-Mendes N, Talvas J, Dualé C et al.: Impact of vitamin $\mathrm{D}$ supplementation on influenza vaccine response and immune functions in deficient elderly persons: a randomized placebocontrolled trial. Front Immunol 2019; 10: 65.

19. Griffin MD, Lutz W, Phan VA et al.: Dendritic cell modulation by 1alpha,25 dihydroxyvitamin $\mathrm{D}_{3}$ and its analogs: a vitamin $\mathrm{D}$ receptor-dependent pathway that promotes a persistent state of immaturity in vitro and in vivo. Proc Natl Acad Sci U S A 2001; 98: 6800-6805.

20. Ricca C, Aillon A, Bergandi L et al.: Vitamin D receptor is necessary for mitochondrial function and cell health. Int J Mol Sci 2018; 19: 1672

21. Rendra E, Riabov V, Mossel DM et al.: Reactive oxygen species (ROS) in macrophage activation and function in diabetes. Immunobiology 2019; 224: 242-253.

22. Chen W, Sandoval H, Kubiak JZ et al.: The phenotype of peritoneal mouse macrophages depends on the mitochondria and ATP/ADP homeostasis. Cell Immunol 2018; 324: 1-7.
23. Naik AL, Rajan MG, Manjrekar PA et al.: Effect of DOTS treatment on vitamin D levels in pulmonary tuberculosis. J Clin Diagn Res 2017; 11: BC18-BC22.

24. Lai CC, Shih TP, Ko WC et al.: Severe acute respiratory syndrome coronavirus 2 (SARS-CoV-2) and coronavirus disease-2019 (COVID-19): the epidemic and the challenges. Int J Antimicrob Agents 2020; 55: 105924.

25. Balasubramanian S, Rao NM, Goenka A et al.: Coronavirus disease (COVID-19) in children - what we know so far and what we do not? Indian Pediatr 2020; 57: 435-442.

26. Cristiani L, Mancino E, Matera L et al.: Will children reveal their secret? The coronavirus dilemma. Eur Respir J 2020; 55: 2000749.

27. Kuchar E, Załęski A, Wronowski $M$ et al.: Children were less frequently infected with SARS-CoV-2 than adults during 2020 COVID-19 pandemic in Warsaw, Poland. Eur J Clin Microbiol Infect Dis 2020: 1-7.

28. Kloc M, Ghobrial RM, Kuchar E et al.: Development of child immunity in the context of COVID-19 pandemic. Clin Immunol 2020; 217: 108510

29. Rusińska A, Płudowski P, Walczak M et al.: Zasady suplementacji i leczenia witaminą D - nowelizacja 2018 r. Stand Med Pediatr 2018; 15: 531-559. 